\title{
FENOMENA AKSI MENYAKITI DIRI BAGI REMAJA DALAM MEDIA ONLINE (ANALISIS TEORI KONSTRUKSI SOSIAL DALAM FENOMENA AKSI MENYAKITI DIRI BAGI REMAJA DALAM MEDIA ONLINE TIRTO.ID)
}

\author{
Ditha Prasanti, Puji Prihandini \\ Fakultas Ilmu Komunikasi, Universitas Padjadjaran \\ Jl.Raya Bandung-Sumedang KM.21 Bandung \\ dithaprasanti@gmail.com
}

\begin{abstract}
The act of self-injury is an action that will have fatal consequences if left unchecked to occur among teenagers today. Recently, the author saw the proliferation of mass media coverage of cases of depression which led to suicide. Anyone can experience it, especially adolescents who in fact are in a period of emotional development, so even this attracts public attention to examine the main root causes of these actions. But in this article, the author wants to highlight one of the news in Tirto.id's online media which discusses the phenomenon of self-injury for junior high school students that occurred in Riau. In the non-participant observations carried out, the authors see that the online media Tirto.id illustrates the existence of self-injury as a form of depression experienced by junior high school students. The self-destructive actions taken were in the form of slashing one's own hand, slapping himself, hitting the wall, banging his head against the wall, and other acts of self-injury. This phenomenon is relevant to the assumptions contained in social construction theory of reality. Tirto.id said that the phenomenon of self-injury has been widespread, both through social media, videos circulating among junior high school students, that it became viral and constructed as a natural reality carried out by these teenagers, as a form of diversion from depression experienced.
\end{abstract}

Keywords: Phenomenon, Social Construction, Self-Suffering Action, Online Media, Tirto id.

\begin{abstract}
Abstrak
Aksi menyakiti diri merupakan tindakan yang akan berakibat fatal jika dibiarkan berkelanjutan terjadi pada kalangan usia remaja saat ini. Baru-baru ini, penulis melihat maraknya pemberitaan media massa tentang kasus depresi yang berujung pada tindakan bunuh diri. Siapapun bisa mengalaminya, khususnya remaja yang notabene berada dalam masa perkembangan emosi, sehingga hal inipun menarik perhatian publik untuk mengkaji akar permasalahan utama yang menjadi penyebab tindakan tersebut. Tetapi dalam artikel ini, penulis ingin menyoroti salah satu pemberitaan dalam media online Tirto.id yang membahas tentang fenomena aksi menyakiti diri bagi remaja pelajar SMP yang terjadi di Riau.

Dalam observasi non partisipan yang dilakukan, penulis melihat bahwa media online Tirto.id menggambarkan adanya aksi menyakiti diri sebagai bentuk dari depresi yang dialami oleh remaja SMP. Aksi menyakiti diri yang dilakukan tersebut berupa menyayat tangan sendiri, menampar diri sendiri, memukul tembok, membenturkan kepala ke tembok, dan aksi menyakiti diri lainnya. Fenomena ini relevan dengan asumsi yang terdapat dalam teori konstruksi sosial atas realitas. Tirto.id menyebutkan bahwa fenomena aksi menyakiti diri sendiri tersebut telah tersebar luas, baik melalui media sosial, video yang beredar di kalangan
\end{abstract}


antar remaja SMP, sehingga menjadi viral dan dikonstruksi sebagai realitas yang wajar dilakukan oleh para remaja tersebut, sebagai bentuk pengalihan dari depresi yang dialaminya.

Keywords: Fenomena, Konstruksi Sosial, Aksi Menyakiti Diri, Media Online, Tirto id.

\section{PENDAHULUAN}

"Beberapa dari mereka juga tidak menggores sendiri tangannya, tapi digores oleh temannya karena kebetulan lewat atau berada di lokasi tersebut," terang Sitti kepada Tirto. (dikutip dari tirto.id)

SH, merupakan salah seorang Komisioner Komisi Perlindungan Anak Indonesia (KPAI) bidang Kesehatan dan NAPZA, yang dalam kesempatan tersebut berhasil diwawancarai oleh tirto.id untuk mengungkapkan tentang salah satu bentuk perilaku komunikasi bagi sebagian remaja di Riau. Kutipan pernyataan di atas yang menarik bagi penulis sehingga ingin mengkaji tentang adanya fenomena aksi menyakiti diri sendiri yang terjadi di kalangan remaja SMP.

Aksi menyakiti diri sendiri dalam tirto.id merupakan aksi menyayat tangannya sendiri. Bahkan, mereka meminta temannya yang kebetulan lewat atau yang berada di lokasi tersebut. Dalam kasus ini, Putri (2018) mengungkapkan aksi menyayat tangan yang dilakukan sebagian remaja SMP di Riau. Data yang diperoleh dari Radio Republik Indonesia (RRI), bahwa motif menggores tangan yang dilakukan para pelajar dipicu oleh sebuah video di Whatsapp. LF, salah satu pelajar yang ikut melakukan aksi menyayat tangan mengaku video tersebut sudah tersebar luas hingga di kalangan pelajar sekolah lain. Sitti kemudian mengungkapkan pernyataan LF dengan keterangan tambahan bahwa LF depresi karena permasalahan keluarga (Putri, 2018).

Fenomena aksi menyakiti diri sendiri yang digambarkan oleh Putri (2018) dalam media online Tirto.id ini merupakan salah satu kasus yang terjadi bagi remaja pelajar SMP di Indonesia. Sebagai bagian dari kajian ilmu komunikasi, kutipan pernyataan Sitti di atas yang menyebutkan bahwa perilaku LF menyayat tangannya tersebut karena mengaku depresi masalah keluarga. Hal ini tentu bukan berarti bahwa penyebab utama aksi mennyayat tangan yang dilakukan remaja tersebut adalah karena depresi masalah keluarga. Apalagi dalam pernyataan di atas juga disampaikan bahwa aksi menyayat tangan tersebut dipicu karena adanya video yang beredar di media sosial whatsapp, sehingga menjadi viral bagi kalangan remaja SMP di Riau.

Penulis juga melihat adanya studi sebelumnya mengenai dampak yang ditimbulkan dari depresi. Penelitian ini 
dilakukan oleh Heene, Bust, dan Oost (2007) tentang kesulitan dalam fungsi psikososial pada orang yang depresi, menggarisbawahi kesulitan yang dialami oleh kedua pasangan.

Dalam penelitiannya, Heene dkk (2007) mengungkapkan informannya memilih komunikasi konflik, atribusi, dan keterikatan sebagai domain penting depresi dalam konteks penyesuaian perkawinan. Pertama, mereka menganalisis apakah sampel klinis pasangan dengan pasien depresi akan berbeda secara signifikan dari kelompok kontrol pada variabel-variabel ini. Kedua, mereka mengeksplorasi sejauh mana variabel-variabel ini memediasi/memoderasi hubungan antara gejala depresi dan penyesuaian perkawinan. Perspektif kedua pasangan diperhitungkan, serta perbedaan gender. Secara total, 69 pasangan klinis dan 69 pasangan kontrol direkrut, dan serangkaian analisis varians multivariat dan analisis regresi dilakukan untuk menguji kedua hipotesis.

Hasil menunjukkan bahwa baik pasien dan pasangannya melaporkan kurang penyesuaian perkawinan yang terkait dengan persepsi negatif yang lebih banyak tentang komunikasi konflik, atribusi kausal, dan kondisi yang tidak aman. Selain itu, komunikasi konflik dan atribusi kausal adalah mediator yang signifikan dari hubungan antara gejala depresi dan penyesuaian perkawinan untuk pria dan wanita yang mengalami depresi, dan atribusi kausal juga memoderasi hubungan ini (Heene, Els; Buysee, Ann;\& Oost Paulette, 2007).

Penelitian berikutnya yang dilakukan oleh Yu Shuli, et.al (2006) yang juga melakukan kajian tentang depresi sebagai bentuk dari penyimpangan perilaku komunikasi. Data dari 752 pemuda Bahama dan orang tua mereka dianalisis untuk menguji hubungan depresi remaja dengan keterlibatan risiko remaja, pemantauan orangtua, dan komunikasi orangtua-remaja.

Remaja yang depresi lebih tua, lebih cenderung terlibat dalam perilaku berisiko, dan mereka merasakan tingkat pemantauan orangtua yang lebih rendah secara signifikan dan tingkat gangguan komunikasi yang lebih tinggi daripada remaja yang tidak depresi. Baik remaja yang tertekan maupun yang tidak depresi mempersepsikan tingkat pemantauan orangtua dan komunikasi terbuka yang secara signifikan lebih rendah dan tingkat komunikasi masalah yang lebih tinggi daripada orang tua mereka, tetapi perbedaan dalam persepsi komunikasi terbuka secara signifikan lebih besar di antara pasangan orang tua-remaja yang depresi. Remaja yang mengalami depresi, remaja dengan riwayat perilaku berisiko masa lalu, remaja yang melaporkan tingkat 
gangguan komunikasi yang lebih tinggi dan pemantauan orangtua yang lebih rendah lebih mungkin mengantisipasi perilaku berisiko di masa depan (Yu, Shuli, et,al., 2006)

Riset yang relevan dengan topik adalah tentang kajian komunikasi intrapersonal oleh Honeycut, Jammes M \& Ford (2016). Dalam penelitiannya diungkapkan bahwa interaksi yang dibayangkan (IIs) adalah jenis kognisi sosial dan citra mental yang didasarkan pada interaksionisme simbolik di mana individu membayangkan percakapan dengan orang lain yang signifikan untuk berbagai tujuan. Konstruk II telah menyediakan mekanisme yang menguntungkan guna mengoperasionalkan studi komunikasi intrapersonal. IIs adalah jenis melamun yang memiliki karakteristik definitif dan melayani sejumlah fungsi termasuk latihan, pemahaman diri, pemeliharaan relasional, mengelola konflik, katarsis, dan kompensasi.

Misalnya, fungsi manajemen konflik menjelaskan bagaimana konflik sulit untuk dikelola dalam kehidupan sehari-hari sehingga sulit untuk "memaafkan dan melupakan." (Honeycut, Jammes M \& Ford, 2016).

Penelitian ketiga di atas berbeda dengan rujukan kedua penelitian sebelumnya yang menitikberatkan pada fenomena depresi. Sementara itu,
Honeycut, Jammes M \& Ford (2016) menyebutkan bahwa komunikasi intrapersonal juga tidak kalah pentingnya karena sebagai dasar dalam membina interaksi, pemahaman diri, pemeliharaan relasional, serta mengelola konflik yang terjadi dalam kehidupan sosial. Disinilah penulis melihat adanya urgensitas pentingnya dilakukan penelitian ini, di mana fenomena aksi menyakiti diri sendiri yang dilakukan remaja SMP dalam media online Tirto.id ini, sebagai bentuk lain dari depresi yang dialami sebagian remaja SMP. Apalagi ditambah dengan kehadiran media baru yang menyebabkan segala hal yang disebarkan melalui media sosial bisa menjadi viral.

Ketika berbagai media mulai gencar memberitakan kejadian bunuh diri baru-baru ini, penulis menemukan berita tentang aksi menyakiti diri sendiri yang dimuat oleh media online tirto.id. Di antara sekian banyaknya pemberitaan bunuh diri dalam akun media online tirto.id, penulis tertarik untuk menyoroti fenomena yang berbeda ini, karena aksi menyakiti diri sendiri sebagai bentuk pengalihan depresi yang dialami oleh sebagian remaja SMP di Riau. Hal ini menarik untuk dikaji bagi penulis. Dalam penelitian ini, penulis menggunakan analisis teori konstruksi sosial untuk mengungkapkan fenoemna aksi menyakiti diri sendiri yang terdapat 
dalam media online tirto.id. Oleh karena itu, berdasarkan latar belakang masalah tersebut, penulis ingin mengungkapkan fenomena aksi menyakiti diri sendiri bagi remaja SMP yang digambarkan dalam media online Tirto.id.

\section{METODE PENELITIAN}

Dalam penelitian ini, penulis menggunakan pendekatan kualitatif dengan metode deskriptif, untuk menggambarkan fenomena yang terjadi di lapangan. Sebagaimana diungkapkan oleh untuk dapat menggali berbagai definisi tentang aksi menyakiti diri, depresi, dan kajian komunikasi intrapersonal lainnya, maka studi literatur menjadi pilihan yang tepat melalui beberapa teks rujukan, jurnal ilmiah, dan beberapa rujukan dari media online.

Selain itu, metode deskriptif juga dipilih karena penelitian yang dilakukan adalah berkaitan dengan peristiwa baru yang sedang berlangsung serta berkaitan dengan kondisi saat ini. Metode deskriptif adalah satu metode untuk meneliti suatu subjek, suatu set kondisi, suatu sistem pemikiran atau pun kelas peristiwa pada masa sekarang. Tujuan dari penelitian deskriptif ini adalah menggambarkan atau melukiskan secara sistematis serta hubungan antar fenomena yang diselidiki (Nazir, M: 2011). Mengenai teknik pengumpulan data, dalam penelitian ini, penulis menggunakan teknik observasi non partisipan dan studi literatur dari berbagai referensi dan kajian yang relevan dengan fokus penelitian ini.

\section{HASIL DAN PEMBAHASAN}

Fenomena aksi menyakiti diri sendiri yang terdapat dalam penelitian penulis ini, bisa juga dinamakan dengan istilah "self injury". Penulis menemukan penelitian terdahulu tentang self injury yang dilakukan oleh Maidah (2013) pada kalangan mahasiswa di Semarang. Maidah mengungkapkan dalam penelitiannya bahwa self injury merupakan suatu bentuk perilaku yang dilakukan individu untuk mengatasi rasa sakit secara emosional dengan cara melukai dirinya sendiri, dilakukan dengan sengaja namun tidak dengan tujuan untuk bunuh diri.

Self injury bertujuan untuk mengubah emosi negatif menjadi emosi positif pada pelakunya. Hasil penelitian menunjukkan bahwa pada perilaku self injury tersebut disebabkan latar belakang keluarga dan lingkungan, misalnya memiliki kepribadian introvert, diri yang rendah, pola pemikiran yang kaku dan sulitnya mengkomunikasikan perasaan. Bentuk self injury yang dilakukan subjek adalah menyayat pergelangan tangan dan mencabuti rambut secara paksa dalam jumlah yang banyak. Self injury dilakukan sesaat setelah pelakunya mengalami 
peristiwa yang menimbulkan emosi negatif dan bisa terjadi akibat adanya proses recalling peristiwa yang menimbulkan emosi negatif pada situasi kesendirian.

$$
\text { Menurut Maidah }
$$
penelitiannya tersebut dapat dijadikan bahan pemahaman atas gambaran perilaku self injury sehingga pelaku dapat segera mencari penanganan psikologis agar tidak berkembang kearah percobaan bunuh diri secara nyata. Selain itu, tentu perlu diadakan penelitian berikutnya mengenai bagaimana membebaskan diri dari perilaku self injury agar penelitian tentang perilaku self injury ini dapat disempurnakan (Maidah, 2013).

Merujuk pada penelitian Maidah (2013) di atas, penulis melihat adanya kesamaan bentuk depresi yang dilakukan oleh remaja SMP dalam media online tirto.id ini, yaitu aksi menyakiti diri sendiri. Bedanya, Maidah (2013) menemukan informan yang juga melakukan self injury lainnya, yaitu menyayat tangan dan mencabuti rambutnya sendiri dalam jumlah banyak. Sedangkan fenomena aksi menyakiti diri sendiri yang dimuat dalam media online tirto.id ini adalah menyayat tangan sendiri, bahkan meminta temannya yang lewat atau sedang berada di lokasi tersebut untuk menyayat tangannya. Fenomena tersebut terjadi pada sebagian kalangan remaja SMP di Riau, yang notabene pada tahun 2013, self injury yang terjadi pada mahasiswa telah diteliti oleh Maidah (2013).

Kondisi demikian perlu mendapatkan penanganan yang serius karena telah terjadi pada lingkungan remaja SMP. Jika Maidah (2013) menyebutkan bahwa self injury dilakukan dengan tujuan untuk mengubah emosi negatif menjadi emosi positif, dalam fenomena aksi menyakiti diri sendiri yang dialami oleh remaja SMP dalam media online tirto.id pun, aksi tersebut merupakan bagian dari bentuk pengalihan depresi. Sebagaimana diungkapkan oleh Putri dalam medi online tirto.id, bahwa rasa sakit fisik merupakan bagian dari pengalihan depresi (Putri, 2018).

Fakta lainnya ditemukan dalam penelitian yang berjudul "Affect Regulation and Addictive Aspects of Repetitive SelfInjury in Hospitalized Adolescents". Nixon, Cloutrieal, \& Agarwal (2002) menyebutkan bahwa kejadian perilaku menyakiti diri sendiri (SIB) pada pasien rawat inap psikiatri remaja telah dilaporkan setinggi $61 \%$, namun sedikit data yang ada tentang karakteristik dan peran fungsional SIB dalam populasi ini. Hal ini disebabkan sifat berulang SIB dan potensinya untuk meningkatkan keparahan, fitur SIB dan efek penguatan spesifiknya diperiksa. Responden dalam penelitian tersebut adalah 42 remaja yang melukai diri sendiri yang dirawat di rumah sakit selama periode 
4 bulan. Sumber data terdiri dari kuesioner laporan diri dan tinjauan grafik medis.

Nixon et.al (2002) mengungkapkan bahwa usia rata-rata adalah 15,7 \pm 1,5 tahun. Desakan yang dilaporkan untuk melukai diri sendiri hampir setiap hari di $78,6 \%$ dari remaja $(\mathrm{n}=33)$, dengan tindakan yang terjadi lebih dari sekali seminggu di 83,3\% ( $\mathrm{n}=35)$. Dua alasan utama yang didukung untuk terlibat dalam aksi melukai diri sendiri adalah "untuk mengatasi perasaan depresi" $(83,3 \%, \mathrm{n}=$ 35) dan "untuk melepaskan ketegangan yang tak tertahankan" $(73,8 \%, \mathrm{n}=31)$. Dari sampel, 97,6\% ( $\mathrm{n}=41)$ mendukung tiga atau lebih gejala adiktif yang dialami oleh para responden (Nixon, Mark; Cloutier, Paula;\& Aggarwal, 2002).

Data yang diungkapkan dalam penelitian Nixon et.al (2002) di atas menguatkan hasil temuan penulis tentang fenomena aksi menyakiti diri sendiri sebagai bentuk pengalihan depresi yang dialami remaja SMP di Riau tersebut. Bedanya, Nixon et.al (2002) menyebutkan self injury tersebut sebagai upaya untuk mengatasi perasaan depresi; melepaskan ketegangan yang tak tertahankan; serta sebagai bagian dari gejala adiktif.

Data pendukung lainnya juga ditemukan dalam artikel yang berjudul "Parental Expressed Emotion and Adolescent Self-Injury”. Penelitian tersebut dilakukan oleh Wedig \& Nock
(2007) ini menguji hubungan antara orangtua yang diekspresikan emosi (EE) dan remaja yang melukai diri sendiri pikiran dan perilaku (SITB), serta mediator potensial dan moderator dari hubungan ini. Jumlah responden yang digunakan adalah 36 orang remaja usia 12 hingga 17 tahun direkrut dari komunitas (2004-2005) memberikan data.

Orang tua dari remaja menyelesaikan Sampel Pidato Lima Menit, ukuran EE berbasis kinerja, dan remaja menyelesaikan wawancara dan skala penilaian menilai SITB, gangguan mental, dan konstruksi terkait. Hasil penelitiannya tersebut mengungkapkan bahwa EE orang tua yang tinggi dikaitkan dengan setiap jenis SITB yang dinilai: ide bunuh diri, rencana bunuh diri, upaya bunuh diri, dan cedera diri nonsuicidal. Analisis juga mengungkapkan bahwa satu komponen spesifik EE (yaitu, kritik orangtua) sangat terkait dengan SITB, sedangkan yang lain (yaitu, keterlibatan emosional yang berlebihan) tidak dan bahwa hubungan antara EE dan SITB tidak dijelaskan oleh adanya gangguan mental. Akhirnya, model moderasi didukung di mana hubungan antara kritik orang tua dan SITB sangat kuat di kalangan remaja dengan gaya kognitif kritis diri. Studi ini menunjukkan bahwa kritik orang tua secara signifikan terkait dengan SITB dan menyarankan satu jalur khusus di mana keluarga dapat 
mempengaruhi SITB remaja (Wedig, Michelle M \& Nock, 2007).

Merujuk pada hasil penelitian Wedig \& Nock (2007) di atas, penulis menemukan adanya self injury yang disebabkan karena adanya depresi pada remaja, tetapi faktor pemicunya karena kritikan dari orang tuanya. Hal tersebut menyebabkan Wedig \& Nock (2007) pun menyebutkan faktor keluarga memegang peranan penting dalam aksi self injury yang dialami remaja, khususnya dengan adanya kritikan dari para orang tua.

Temuan lainnya, aksi menyakiti diri sendiri ini merupakan bentuk pengalihan depresi, di mana depresi ini menandakan ada sesuatu yang salah dalam sistem komunikasi intrapersonal yang dialami oleh seorang individu. Sistem komunikasi intrapersonal merupakan proses komunikasi yang terjadi dalam diri individu, secara internal, di mana alurnya terdiri dari tahapan sensasi, persepsi, memori, dan berpikir. Penulis melihat depresi tersebut terjadi dalam tahapan sistem komunikasi intrapersonal yang dialami oleh remaja. Dalam usia 12- 13 tahun, ketika remaja melihat ada tren baru dalam pengalihan depresi sebagai tahap sensasi, maka di tahap berikutnya yaitu persepsi, mereka membuat konstruksi sosial atas realitas, sehingga masuk ke tahapan memori, dan yang terakhir adalah berpikir, yaitu memilih memutuskan untuk ikut tren dalam mengalihkan depresi, serta rasa penasaran mencoba hal baru yang menjadi viral tersebut, yaitu aksi menyayat tangan, sebagai bentuk pengalihan depresi.

Pada bagian di bawah ini, penulis akan memaparkan faktor penyebab aksi menyakiti diri sendiri pada remaja SMP yang diungkapkan oleh media online tirto.id. Penulis juga membahas keterkaitan analisis teori konstruksi sosial atas realitas dengan fenomena aksi menyakiti diri sendiri yang terdapat dalam media online tirto.id tersebut.

\section{Identifikasi "Aksi Menyakiti Diri Sendiri" sebagai bentuk Pengalihan Depresi bagi Anak dalam media online tirto.id}

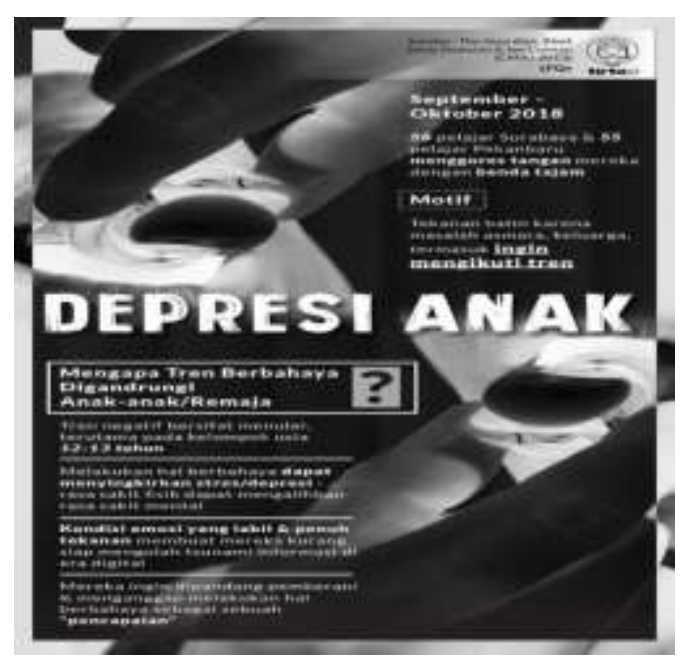

(Sumber: media online tirto.id, 2018)

Gambar di atas merupakan infografis yang penulis temukan dalam media online tirto.id, sebagai bentuk representasi dari fenomena aksi menyakiti 
diri sendiri yang dialami sebagian remaja SMP di Riau. Putri (2018) dalam artikelnya tersebut mengidentifikasi bahwa ada beberapa alasan yang melatarbelakangi aksi self injury tersebut dilakukan oleh anak dan remaja.

Alasan pertama, penulis melihat sebagaimana diungkapkan oleh Nixon et.al (2002) bahwa aksi self injury tersebut sebagai akibat dari adiksi media sosial. Jika dalam kasus ini, penulis melihat adanya perilaku negatif yang menular dalam melakukan aksi menyayat tangannya sendiri, bahkan meminta temannya yang lewat saat itu untuk menyayat tangannya. Apalagi ditambah dengan adanya video yang beredar dalam media sosial, sehingga menjadi viral. Hal ini menandakan seolaholah aksi tersebut pun sedang menjadi tren bagi kalangan remaja, dan layak diikuti sebagai media pengalihan depresi.

Alasan kedua, penulis setuju dengan temuan dalam media online tirto.id tersebut bahwa anak dan remaja melakukan hal berbahaya itu adalah untuk menyingkirkan stres atau depresi. Rasa sakit fisik mengalihkan sementara rasa sakit mental yang mereka derita. Data dari NHS Digital, yang diperoleh Guardian menunjukkan jumlah anak usia 3-9 tahun di Inggris yang melakukan aksi menyakiti diri sendiri meningkat 27 persen dari 20122017 (Putri, 2018).
Putri (2018) juga menyebutkan bahwa ada banyak anak berusia mulai dari tiga tahun yang menggosok kulit menggunakan karet, membenturkan kepala ke dinding, mencabut rambut, menggigit, menggaruk, dan menampar diri sendiri. Anak dan remaja juga kurang memiliki kesiapan mental untuk mengolah banyaknya informasi di internet. Emosi yang tak stabil, penuh tekanan emosional, dan ragam konflik remaja membuat mereka mudah terjebak paparan negatif internet. Aksi menyakiti diri dijadikan media penyaluran, berkembang dengan manipulasi serta memainkan emosi anak dan remaja (Putri, 2018).

Alasan ketiga, penulis juga sepakat bahwa Putri (2018) menyebutkan anak dan remaja seringkali ingin mengikuti tren yang ada, ingin dipandang "mampu" dan pemberani. Menerima tantangan dari kelompok sosialnya artinya memberi klaim pencapaian. Ada dua tipe anak yang berpeluang terjerat, yakni anak tipe pemberani/petualang dan tipe yang sering diejek sebagai "pecundang". Kelompok terakhir seringkali merasa menemukan teman ketika menerima tantangan mengerikan itu (Putri, 2018).

Alasan keempat, penulis melihat bahwa kategori usia remaja SMP tersebut, pada rentang usia 12-13 tahun masih memiliki rasa penasaran ingin mencoba, gejala adiksi internet tadi menyebabkan 
mereka menonton video aksi menyayat tangan yang sedang viral tersebut, sehingga ada rasa ingin mencoba hal yang sama, sebagai upaya pengalihan depresi. Padahal sebenarnya bisa jadi depresi yang mereka alami pun ternyata masalah biasa saja, tetapi menjadi masalah yang besar. Tetapi ada juga yang memang mengalami tekanan berat akibat masalah keluarga, asmara, bullying dalam lingkungan sosial, dan pertemanan.

Dalam tabel di bawah ini, penulis mengidentifikasi temuan yang terdapat dalam media online tirto.id, yang dikolaborasi dengan data pendukung dari beberapa jurnal ilmiah internasional tentang aksi self injury bagi kalangan usia anak dan remaja.

Tabel 1.

Identifikasi Penyebab Aksi Menyakiti Diri

Sendiri bagi Remaja dalam media online

Tirto.id

\begin{tabular}{|l|l|l|}
\hline No & \multicolumn{1}{|c|}{$\begin{array}{c}\text { Faktor } \\
\text { Penyebab }\end{array}$} & $\begin{array}{l}\text { Pernyataan } \\
\text { gejala penyebab } \\
\text { Aksi Menyakiti } \\
\text { Diri Sendiri }\end{array}$ \\
\hline 1. & $\begin{array}{l}\text { Gejala adiksi } \\
\text { internet, } \\
\text { khususnya } \\
\text { sesuatu yang } \\
\text { menjadi viral } \\
\text { dalam media } \\
\text { sosial }\end{array}$ & $\begin{array}{l}\text { Dilansir laman } \\
\text { Radio Republik } \\
\text { Indonesia (RRI), } \\
\text { motif menyilet } \\
\text { tangan yang } \\
\text { dilakukan para } \\
\text { pelajar dipicu } \\
\text { oleh sebuah video } \\
\text { di Whatsapp. }\end{array}$ \\
\hline 2. & $\begin{array}{l}\text { Pengalihan } \\
\text { depresi, } \\
\text { melepaskan } \\
\text { ketegangan yang } \\
\text { tak tertahankan }\end{array}$ & $\begin{array}{l}\text { Rasa sakit fisik } \\
\text { adalah salah satu } \\
\text { media pengalihan } \\
\text { depresi }\end{array}$ \\
\hline 3. & $\begin{array}{l}\text { Kondisi emosi } \\
\text { yang labil, ingin }\end{array}$ & $\begin{array}{l}\text { "Beberapa dari } \\
\text { mereka juga tidak }\end{array}$ \\
\hline
\end{tabular}

\begin{tabular}{|c|c|c|}
\hline & $\begin{array}{l}\text { dipandang } \\
\text { "mampu dan } \\
\text { pemberani" } \\
\text { dalam mencoba } \\
\text { aksi menyakiti } \\
\text { diri sendiri } \\
\text { dengan cara } \\
\text { menyayat } \\
\text { tangannya sendiri } \\
\text { atau meminta } \\
\text { tolong temannya } \\
\text { yang } \\
\text { melakukannya }\end{array}$ & $\begin{array}{l}\text { menggores } \\
\text { sendiri } \\
\text { tangannya, tapi } \\
\text { digores oleh } \\
\text { temannya karena } \\
\text { kebetulan lewat } \\
\text { atau berada di } \\
\text { lokasi tersebut," } \\
\text { terang Sitti } \\
\text { kepada Tirto. }\end{array}$ \\
\hline 4. & $\begin{array}{l}\text { Rasa penasaran } \\
\text { ingin mencoba } \\
\text { hal yang sedang } \\
\text { menjadi tren, } \\
\text { yaitu aksi self } \\
\text { injury dalam } \\
\text { bentuk } \\
\text { menyayat } \\
\text { tangannya } \\
\text { sendiri }\end{array}$ & $\begin{array}{l}\text { Para siswi } \\
\text { mengaku } \\
\text { mengalami } \\
\text { tekanan batin } \\
\text { akibat masalah } \\
\text { asmara, } \\
\text { keluarga, } \\
\text { hingga } \\
\text { tertantang } \\
\text { mengikuti tren. }\end{array}$ \\
\hline
\end{tabular}

(Sumber: Olahan Penulis, 2018)

Analisis Teori Konstruksi Sosial tentang Fenomena Aksi Menyakiti Diri Sendiri bagi Remaja dalam media online tirto.id

Dalam penelitian ini, penulis melihat adanya asumsi teori konstruksi sosial atas realitas yang relevan dengan fenomena yang digambarkan dalam media online tirto.id ini. Tokoh dari teori Konstruksi Sosial ini adalah Peter L. Berger dan Thomas Luckmann.

Berger dan Luckmann berpandangan bahwa kenyataan itu dibangun secara sosial, sehingga sosiologi pengetahuan harus menganalisis proses terjadinya itu. Dalam pengertian individuindividu dalam masyarakat itulah yang membangun masyarakat, maka pengalaman individu tidak terpisahkan 
JURNAL NOMOSLECA

Volume 5 Nomor 2, Oktober 2019

dengan masyarakatnya. Waters mengatakan bahwa "they start from the premise that human beings construct sosial reality in which subjectives process can become objectivied". ( Mereka mulai dari pendapat bahwa manusia membangun kenyataan sosial di mana proses hubungan dapat menjadi tujuan yang nyata). Pemikiran inilah barangkali yang mendasari lahirnya teori sosiologi kontemporer "konstruksi sosial" (Sukidin \& Bosrowi, 2002).

Dalam penelitian ini, penulis melihat bahwa maksud pernyataan di atas terdapat jelas dalam fenomena aksi menyakiti diri sendiri yang dialami sebagian remaja tersebut. "Manusia dalam hal ini adalah para remaja" yang membangun kenyataan sosial di mana proses hubungan "aksi menyakiti diri sendiri" yang diberitakan dalam media online tirto.id, dapat menjadi tujuan yang nyata. Tujuan yang dimaksud dalam fenomena yang diberitakan ini adalah salah satunya sebagai bentuk pengalihan depresi bagi remaja tersebut.

Berger dan Luckman (Bungin, 2008:15) mengatakan terjadi dialektika antara indivdu menciptakan masyarakat dan masyarakat menciptakan individu. Dalam hal ini, individu yang dimaksud adalah para remaja yang melakukan aksi menyakiti diri sendiri. Proses dialektika ini terjadi melalui eksternalisasi, objektivasi, dan internalisasi.

Pertama, eksternalisasi, yaitu usaha pencurahan atau ekspresi diri manusia ke dalam dunia, baik dalam kegiatan mental maupun fisik. Dalam proses inilah dihasilkan suatu dunia dengan kata lain, manusia menemukan dirinya sendiri dalam suatu dunia. Tahap eksternalisasi ini jelas terlihat dalam fenomena aski menyakiti diri sendiri yang dialami oleh remaja yang melakukan tindakan menyayat tangannya tersebut. Mereka melakukan proses eksternalisasi yaitu ekspresi diri untuk menunjukkan aksinya sebagai bentuk pengalihan depresi yang dialaminya.

Kedua, objektivasi, yaitu hasil yang telah dicapai baik mental maupun fisik dari kegiatan eksternalisasi manusia tersebut. Hasil dari eksternalisasi kebudayaan itu misalnya, remaja yang menciptakan realitas kebudayaan non-materiil dalam bentuk aksi menyakiti diri sendiri. Setelah dihasilkan, produk eksternalisasi tersebut menjadi realitas yang objektif. Realitas objektif tersebut, dalam hal ini, menjadi kenyataan empiris yang bisa dialami oleh setiap remaja yang merasa tertantang untuk mencoba aksi menyayat tangan, sebagai tren baru untuk mengalihkan depresi yang dialaminya.

Ketiga, internalisasi. Proses internalisasi, di mana manusia menjadi hasil dari masyarakat. Dalam hal ini, 
realitas yang tidak terbentuk begitu saja, tetapi aksi menyakiti diri sendiri menjadi realitas yang menggambarkan kondisi pengalihan depresi yang dialami oleh sebagian kalangan anak dan remaja yang ada. Bagi Berger, realitas itu tidak dibentuk secara ilmiah, tidak juga sesuatu yang diturunkan oleh Tuhan. Tetapi sebaliknya, ia dibentuk dan dikonstruksi. Realitas tentang aksi menyakiti diri sendiri sebagai bentuk pengalihan depresi itu merupakan realitas yang dikonstruksi oleh para remaja yang mengalaminya, dalam media online tirto.id tersebut.

Dengan pemahaman semacam ini, realitas berwajah ganda. Setiap orang bisa mempunyai konstruksi yang berbeda-beda atas suatu realitas. Setiap orang yang mempunyai pengalaman, preferensi, pendidikan tertentu, dan lingkungan pergaulan atau sosial tertentu akan menafsirkan realitas sosial itu dengan konstruksinya masing-masing (Bungin, 2008).

\section{PENUTUP}

\section{Simpulan dan Saran}

Melalui artikel ini, penulis mengungkapkan tentang fenomena aksi menyakiti diri sendiri, self injury, yang terdapat dalam pemberitaan media online tirto.id. Aksi menyakiti diri yang dilakukan tersebut bisa berupa menyayat tangan sendiri, menampar diri sendiri, memukul tembok, membenturkan kepala ke tembok, dan aksi menyakiti diri lainnya. Tetapi aksi menyakiti diri sendiri yang disoroti dalam media online tirto.id tersebut adalah aksi menyayat tangannya sendiri. Fenomena ini relevan dengan asumsi yang terdapat dalam teori konstruksi sosial atas realitas. Tirto.id menyebutkan bahwa fenomena aksi menyakiti diri sendiri tersebut telah tersebar luas, baik melalui media sosial, video yang beredar di kalangan antar remaja SMP, sehingga menjadi viral dan dikonstruksi sebagai realitas yang wajar dilakukan oleh para remaja tersebut, sebagai bentuk pengalihan dari depresi yang dialaminya.

Berawal dari ketertarikan penulis untuk mengupas fenomena tersebut, penulis berharap dapat melakukan penelitian selanjutnya untuk mendalami upaya strategis berkaitan dengan penanganan solutif untuk menyikapi fenomena aksi menyakiti diri sendiri tersebut. Sebagaimana ungkapan nyata bahwa "mencegah lebih baik daripada mengobati", begitupun halnya dalam kasus yang disoroti oleh media online tirto.id tersebut. 


\section{DAFTAR PUSTAKA}

Bungin, B. (2008). Sosiologi KomunikasiTeori, Paradigma, dan Diskursus

Teknologi Komunikasi di

Masyarakat. Jakarta: Kencana.

Heene, Els; Buysee, Ann;\& Oost Paulette,

V. (2007). An Interpersonal

Perspective on Depression: The Role of Marital Adjustment, Conflict

Communication, Attributions, and

Attachment Within a Clinical

Sample. Family Process, 46(4).

Honeycut, Jamess M \& Ford, S. G.

(2016). Mental Imagery and

Intrapersonal Communication: A

Review of Research on Imagined

Interactions (IIs) and Current

Developments. Annals of the

International Communication

Association, 25(1).

Maidah, D. (2013). SELF INJURY PADA

MAHASISWA (STUDI KASUS

PADA MAHASISWA PELAKU

SELF INJURY). Developmental and

Clinical Phsycology, 2(1).

Nazir.Mohammad, P. . (2011). Metode

Penelitian. Jakarta: Ghalia Indonesia.

Nixon, Mark; Cloutier, Paula;\&

Aggarwal, S. (2002). Affect

Regulation and Addictive Aspects of
Repetitive Self-Injury in Hospitalized

Adolescents. Journal of American

Academy of Child \& Adolescent

Phsychiatry, 41(11).

Putri, A. W. (2018). Mengiris Tangan,

Sakiti Diri: Bisa Jadi Anak Depresi.

Retrieved from

https://tirto.id/mengiris-tangan-sakitidiri-bisa-jadi-anak-depresi-c8KH

Sukidin, B. dan. (2002). Metode

Penelitian Perspektif Mikro:

Grounded theory, Fenomenologi,

Etnometodologi, Etnografi,

Dramaturgi, Interaksi Simbolik,

Hermeneutik, Konstruksi Sosial,

Analisis Wacana, dan Metodologi

Refleksi. Surabaya: Insan Cendekia.

Wedig, Michelle M;Nock, M. K. (2007).

Parental Expressed Emotion and

Adolescent Self-Injury. Journal of

American Academy of Child \&

Adolescent Phsychiatry, 46(9).

Yu, Shuli, D. (2006). YOUTH AND

PARENTAL PERCEPTIONS OF

PARENTAL MONITORING AND

PARENT-ADOLESCENT

COMMUNICATION, YOUTH

DEPRESSION, AND YOUTH RISK

BEHAVIORS. Social Behaviour and

Personality, 34(10). 